Article

\title{
A Static Pulling Test Is a Suitable Method for Comparison of the Loading Resistance of Silver Birch (Betula pendula Roth.) between Urban and Peri-Urban Forests
}

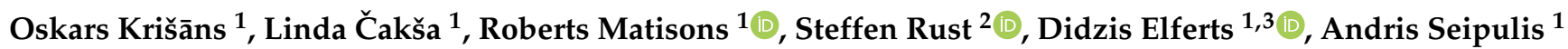 \\ and Āris Jansons ${ }^{1, *}$
}

1 Latvian State Forest Research Institute 'Silava', 111 Rigas Str., LV-2169 Salaspils, Latvia; oskars.krisans@silava.lv (O.K.); linda.caksa@silava.lv (L.Č.); roberts.matisons@silava.lv (R.M.); didzis.elferts@lu.lv (D.E.); andris.seipulis@silava.lv (A.S.)

2 Faculty of Resource Management, University of Applied Sciences and Arts, Büsgenweg 1a, 37077 Göttingen, Germany; steffen.rust@hawk.de

3 Faculty of Biology, University of Latvia, 1 Jelgavas Str., LV-1004 Riga, Latvia

* Correspondence: aris.jansons@silava.lv; Tel.: +371-2-910-9529

check for

updates

Citation: Krišāns, O.; Čakša, L.;

Matisons, R.; Rust, S.; Elferts, D.;

Seipulis, A.; Jansons, A. A Static

Pulling Test Is a Suitable Method for

Comparison of the Loading

Resistance of Silver Birch (Betula

pendula Roth.) between Urban and

Peri-Urban Forests. Forests 2022, 13,

127. https://doi.org/10.3390/

f13010127

Academic Editor: Jean-Claude Ruel

Received: 15 December 2021

Accepted: 13 January 2022

Published: 16 January 2022

Publisher's Note: MDPI stays neutral with regard to jurisdictional claims in published maps and institutional affiliations.

Copyright: (C) 2022 by the authors. Licensee MDPI, Basel, Switzerland. This article is an open access article distributed under the terms and conditions of the Creative Commons Attribution (CC BY) license (https:// creativecommons.org/licenses/by/ $4.0 /)$.

\begin{abstract}
In urbanized areas, wind disturbances can be intensified by anthropogenic stresses under which trees may become hazardous, creating serious threats and damages to nearby targets. Therefore, species with notably lower both wood mechanical properties and compartmentalization, such as pioneers, are considered to have higher wind damage risk if subjected to unfavorable growing conditions. Eurasian aspen (Populus tremula L.) and silver birch (Betula pendula Roth.), are frequently found in both urban and peri-urban forests in Northeastern and Central parts of Europe, which strengthen the necessity for the evaluation of mechanical stability of such species. Therefore, static pulling tests were performed to compare the mechanical stability of the studied species in both urban and peri-urban forests. The loading resistance of the studied species differed, with birch being more stable than aspen, indicating aspen to be more prone to wind damage. Additionally, the mechanical stability of birch did not differ between trees growing in urban and peri-urban forests, suggesting static pulling tests are a suitable method for comparing trees from completely different growing conditions.
\end{abstract}

Keywords: tree-pulling tests; wind resistance; wind damage; urban forest; Populus tremula; Betula pendula

\section{Introduction}

Tendencies in urbanization indicate the spread of urban areas in both size and populations [1,2]. Both urban and peri-urban forests are highly important in facilitating the quality of life in urban areas as they provide functions such as mitigation of urban heat islands [3], regulation of rainwater runoff [4], reduction of air pollution [5], and recreational services [6]. Thus, the need for appropriate management of urban and peri-urban forests is expected to increase to provide satisfactory microenvironments in both residential and public areas [7].

Trees in urbanized environments are subjected to unfavorable growing conditions with limited growing space that primarily limits nutrient and water supply [8]. Natural disturbances, such as storms, temperature stress, and droughts are also potential threats for forests directly surrounding highly urbanized areas, especially as they are intensified by climate change [9-11]. In urbanized areas, such disturbances may be stronger when combined with additional anthropogenic stresses, under which trees may lose vitality and become hazardous [12]. Reduction of tree mechanical stability is particularly significant as potential targets are often present in urbanized areas [13]. Therefore, the evaluation of mechanical stability of trees is a significant part of management of urban green areas [14]. 
Tree mechanical stability, specifically the strength of the soil-root anchorage and stem strength, can be quantified under static loading as the maximum resistive turning moments at the stem and stem base, respectively $[15,16]$. The insufficiency in either of these characteristics leads to tree failure either as uprooting or stem breakage [15] — under sufficient soil-root anchorage stem breakage occurs; however, stem stiffness depends on material properties of wood as well as tree dimensions [17]. Soil-root anchorage is largely determined by microsite growing conditions [18] as binding between roots and soil is affected by spatial distribution of roots and soil parameters [15,19]. In urban areas, these might be worse than in forests, as anchorage is more likely to be compromised by technogenic factors [20-22]. However, to the authors' knowledge, no study has compared the mechanical stability of urban and forest trees using a static tree-pulling test method so far. It is an important aspect for urban forestry as urbanized areas tend to merge with peri-urban forests, especially when fast-growing tree species, such as pioneers [23], rapidly succeed on open sites developing stands in unmanaged urban settings [24].

Pioneers are associated with lower wood mechanical properties as well as capabilities in compartmentalizing of decay $[25,26]$. Additionally, pioneers are early successional and shade-intolerant species that form the main canopy of stand; thus, they are subjected to heavier wind loads than trees below them [27]. Such characteristics might result in pioneers having relatively shorter life spans compared to species from other ecological niches [28]. However, pioneers are often found in urban green areas [29] as capabilities of rapid growth and forming wide canopies with large surface area of the leaves are required [30]. Such criteria can be met by species such as Eurasian aspen (Populus tremula L.) and silver birch (Betula pendula Roth.), which are widely distributed in Northeastern and Central parts of Europe and can frequently be found in both urban and peri-urban forests [31-33]. Additionally, both species have high esthetical and ecological value [34].

Considering their high regional importance, it is crucial to assess the mechanical stability of both species in terms of developing tree management applications for local conditions [35,36]. To date, information about mechanical stability of aspen is lacking, while birch trees with relatively small dimensions or individuals growing in waterlogged forest sites have been tested [37]. Furthermore, frequent occurrence of overgrown individuals of both species in urbanized areas strengthens the necessity for the evaluation of the mechanical stability of such trees, especially as they are pioneers with a shorter life span $[13,34]$. Therefore, the aim of this study is to compare the mechanical stability of mature individuals of Eurasian aspen and silver birch. We hypothesize that birch has higher mechanical stability compared to aspen, thereby it is more resistant to wind disturbance. Additionally, the applicability of static tree-pulling tests for both urban and forest trees has to be evaluated to test the hypothesis that methods to estimate mechanical stability of trees and thresholds used in this process can be applied regardless of the growing environment.

\section{Materials and Methods}

\subsection{Study Site and Sample Trees}

\subsubsection{Forest Sites}

Forest sites were located in Eastern Baltic region, in Latvia, where more than half of the territory is covered by forests [38]. Aspen and birch are very common broadleaves, together comprising ca. $35.5 \%$ of forest territory in Latvia [39]. Both species spread vigorously, forming both pure and mixed stands and occupying new openings [40]. In Latvia, urban areas are relatively small and situated close to forests, thus the tree species found in forests are successfully acclimated in urban environment and the opposite [41]. Thus, both aspen and birch are frequently found in urban areas, mostly in long-term unmanaged surroundings, and they reach considerable dimensions in a relatively short period of time [42].

The climate in Latvia is humid continental [43] and strongly influenced by the dominant westerlies from North Atlantic, with the highest wind speeds in autumn-winter season especially in western part of Latvia [44]. The mean sum of precipitation in the 
territory of Latvia is $692 \mathrm{~mm}$ with the highest mean monthly sum $(77 \mathrm{~mm})$ reaching in July [45]. The warmest month is July $\left(+17.4{ }^{\circ} \mathrm{C}\right)$ and coldest in February $\left(-3.7^{\circ} \mathrm{C}\right)$. Mean annual air temperature and wind speed are higher and in western part of Latvia, reaching $+7.4{ }^{\circ} \mathrm{C}$ and $4 \mathrm{~m} \mathrm{~s}^{-1}$, respectively, while in uplands eastwards they both decrease to $+5.2{ }^{\circ} \mathrm{C}$ and $2.5 \mathrm{~m} \mathrm{~s}^{-1}$, respectively. The highest mean annual air temperature reaches $+7.9^{\circ} \mathrm{C}$ in the largest city, Riga, under the effect of urban heat island [45,46].

Study sites were located in research forest areas with similar wind conditions [47] in central and eastern parts of Latvia near Jelgava $\left(56^{\circ} 42^{\prime} \mathrm{N} ; 23^{\circ} 50^{\prime} \mathrm{E}\right)$ and Smiltene $\left(57^{\circ} 18^{\prime} \mathrm{N}\right.$; $25^{\circ} 55^{\prime} \mathrm{E}$ ), respectively. All 6 studied forest sites were dominated by mature aspen or birch (admixture species $\leq 20 \%$ of standing volume) (Table 1 ). According to forest inventory data, mean stand age for aspen stands were 66 years, while birch stands were ca. 87 years old. In total, 37 vital canopy trees without visual signs of mechanical damage were selected. Mean DBH for aspen tended to be larger (site No. 5, Table 1). Trees growing on edges of stands or close to each other were avoided in order to minimize the effect of uneven distribution of adaptation of mechanical stability.

Table 1. Tree species composition (proportion from the standing volume), the number of sampled trees (Tree N) mean ( $\pm 95 \%$ confidence interval) diameter at breast height $(\mathrm{DBH})$, height $(\mathrm{H})$, stemwood volume $\left(\mathrm{V}_{\text {stem }}\right)$, root depth of uprooted sample trees, and gravimetric water content $\left(\mathrm{GWC}_{\text {soil }}\right)$ and density of soil of each sampled site. Tree species abbreviated as follows: A-common aspen (Populus tremula L.); B-birch (Betula pendula Roth.), G-gray alder (Alnus incana (L.) Moench.); $\mathrm{P}-$ Scots pine (Pinus sylvestris L.).

\begin{tabular}{|c|c|c|c|c|c|c|c|c|}
\hline Site No. & $\begin{array}{c}\text { Composition } \\
(\%)\end{array}$ & $\mathbf{N}$ & DBH (cm) & H (m) & $V_{\text {stem }}\left(\mathrm{m}^{3}\right)$ & $\begin{array}{c}\text { Root } \\
\text { Depth (m) }\end{array}$ & $\begin{array}{c}\mathrm{GWC}_{\text {soil }} \\
(\%)\end{array}$ & $\begin{array}{l}\text { Soil Density } \\
\left(\mathrm{kg} \mathrm{m}^{-3}\right)\end{array}$ \\
\hline \multicolumn{9}{|l|}{ Aspen } \\
\hline 1 & $\mathrm{~A}(100)$ & 6 & $33.8 \pm 3.8$ & $36.0 \pm 1.8$ & $1.55 \pm 0.39$ & $0.60 *$ & $11.1 \pm 3.3$ & $1144 \pm 36$ \\
\hline 2 & $\mathrm{~A}(90), \mathrm{B}(10)$ & 2 & $31.3 \pm 2.2$ & $32.3 \pm 4.4$ & $1.19 \pm 0.32$ & 0.75 * & $8.7 \pm 1.2$ & $1146 \pm 58$ \\
\hline 3 & $\mathrm{~A}(80), \mathrm{B}(20)$ & 6 & $34.4 \pm 4.4$ & $32.6 \pm 1.0$ & $1.46 \pm 0.41$ & - & $17.0 \pm 5.6$ & $1009 \pm 128$ \\
\hline 4 & $\mathrm{~A}(80), \mathrm{B}(20)$ & 4 & $35.8 \pm 4.1$ & $34.5 \pm 2.4$ & $1.66 \pm 0.46$ & $0.64 \pm 0.19$ & $13.5 \pm 5.3$ & $1058 \pm 104$ \\
\hline \multicolumn{9}{|l|}{ Birch } \\
\hline 5 & $\mathrm{~B}(90), \mathrm{G}(10)$ & 10 & $25.5 \pm 1.8$ & $29.1 \pm 1.3$ & $0.67 \pm 0.10$ & $0.85 \pm 0.10$ & $5.9 \pm 1.2$ & $969 \pm 31$ \\
\hline 6 & $\mathrm{~B}(90), \mathrm{P}(20)$ & 9 & $35.0 \pm 3.9$ & $32.8 \pm 1.3$ & $1.43 \pm 0.32$ & $0.84 \pm 0.10$ & $7.4 \pm 0.7$ & $1014 \pm 38$ \\
\hline Karlsruhe & - & 21 & $37.9 \pm 3.6$ & $19.9 \pm 1.4$ & $1.07 \pm 0.20$ & - & - & - \\
\hline Hamburg & - & 14 & $38.9 \pm 4.2$ & $18.8 \pm 1.5$ & $1.08 \pm 0.30$ & - & - & - \\
\hline
\end{tabular}

* single tree uprooted.

All stands were situated on drained mineral soils. Soil parameters, such as moisture and density (Table 1) were tested in a laboratory. Samples in the volume of $100 \mathrm{~mL}$ were taken at the base of each tree at the depths of 0-10, 10-20, 20-40, and 40-80 cm and placed in hermetically sealed packaging. Samples were dried in $105^{\circ} \mathrm{C}$ temperature for $24 \mathrm{~h}$, and the difference between initial and dry weight was expressed as gravimetric water content of soil $\left(\mathrm{GWC}_{\text {soil }}\right.$ in \%) for each sampled depth (Table 1). Soil density (in $\mathrm{kg} \mathrm{m}^{-3}$ ) was determined for dried samples.

\subsubsection{Urban Sites}

Data on mechanical stability of urban birch were obtained in 2 cities in Germany (Hamburg and Karlsruhe). Similar to Latvia, in regions of both cities birch is a native pioneer tree species [48], and such distinct locations of forest and urban sites are considered to have determined different growth patterns of sampled trees [49]. The climate in both Hamburg and Karlsruhe is oceanic with strong maritime influences from the Atlantic Ocean [43]. In both cities, dominant winds are westerlies with mean annual wind speeds of 3.9 and $3 \mathrm{~m} \mathrm{~s}^{-1}$ for Hamburg and Karlsruhe, respectively. Winters in both cities are milder compared with Latvia as mean air temperatures of the coldest month (January) are 
$+1.0^{\circ} \mathrm{C}$ for Hamburg and $+2.0^{\circ} \mathrm{C}$ for Karlsruhe. In Hamburg highest mean air temperature in summers (July) appear to be the same as in Latvia $\left(+17.4^{\circ} \mathrm{C}\right)$; however, the mean annual air temperature is higher reaching $+9{ }^{\circ} \mathrm{C}$. Karlsruhe is considered as one of sunniest and warmest cities of Germany as mean annual air temperature reaches $+11^{\circ} \mathrm{C}$ with warmest month in July $\left(+20.6^{\circ} \mathrm{C}\right)$ [50]. Meanwhile, in both cities mean annual sum of precipitation is similar-792 $\mathrm{mm}$ for Hamburg and $783 \mathrm{~mm}$ for Karlsruhe [50,51].

Both urban sites were located in urban settlement outskirts of the city centers. In Hamburg, 14 mature trees were sampled in an unmanaged building plot overgrown with trees $\left(3000 \mathrm{~m}^{2}\right)$ in the residential area of the quarter of Lohbrügge $\left(53^{\circ} 30^{\prime} 44.9^{\prime \prime} \mathrm{N}\right.$; $\left.10^{\circ} 10^{\prime} 01.2^{\prime \prime} \mathrm{E}\right)$. The sampled site is located on podzolic and gleyed sandy soil $30 \mathrm{~m}$ above sea level on the northern part of slope of the Elbe glacial valley. In Karlsruhe, the studied site was a paved urban parking lot with trees growing on the separating lanes, thus tree rooting was restricted. This place is called Birkenparkplatz $\left(49^{\circ} 01^{\prime} 17.9^{\prime \prime} \mathrm{N}, 8^{\circ} 24^{\prime} 52.4^{\prime \prime} \mathrm{E}\right)$ in a sports facility area in Waldstadt area, and 21 mature birch were sampled there before the reconstruction works began. This site was located $118 \mathrm{~m}$ above sea level and the pedogenesis is anthropogenic as most of the test area was used as a roadway. Sampled trees were located in strips that separated parking lots. Selection of trees from explicitly different growing environments enabled the testing of the hypothesis regarding comparability of tree-stability estimates obtained by static pulling tests.

\subsection{Static Pulling Tests}

Static pulling of trees was performed during August-September 2021 in accordance with methods applied by Krišāns et al. [37,52,53]. Schematic description of the setup is provided in the supplementary material (Figures S1 and S2). In brief, the de-topped trees were pulled destructively until the tree failure as uprooting or stem breakage occurred [54]. De-topping of sample trees was performed in order to avoid the influence of wind and canopy weight on the measurement. Pulling line was formed as a block system of four pulleys using polyester rope (diameter $12 \mathrm{~mm}$ ) and two opposite located Roll Double pulleys (Edelrid, Germany). Additional unit of $12 \mathrm{~mm}$ polyester rope was used to extend the pulling line. On the sample tree, the pulling line was placed at the half of the total height and $1 \mathrm{~m}$ below the height of the de-topping to prevent the anchoring round-sling from slipping over. Pulling line was anchored at the base of a tree located opposite to the sample tree in the distance of 30-40 m. A 2-stroke portable motor winch-1800 Capstan Cable Winch (Nordforest, Grube Group, Germany) —-was used to apply continuous and even force for pulling. The winch was placed in the distance of at least $5 \mathrm{~m}$ away from the anchoring tree of pulling line at the base of another tree. The angle between the winch and puling line did not exceed $30^{\circ}$.

The TreeQinetic System (Argus Electronic GmbH, Rostock, Germany) was used for measurements. Pulling force and the slope angle of the pulling line and was measured with a dynamometer placed in between the pulley block system and extension of pulling line. Tilt measurements of sample trees were performed simultaneously at the base of the stem and at the height of $5 \mathrm{~m}$ by using inclinometers. A strain gauge was used to measure the deformation of wood fibre on the compression side of the stem at the height of $1 \mathrm{~m}$.

\subsection{Data Processing and Analysis}

The basal bending moment (BBM, in $\mathrm{kNm}$ ) was calculated for each tree using obtained pulling force and the slope angle of the pulling line as follows:

$$
B B M=F \times h_{\text {anchor }} \times \cos \left(\text { median }\left(\alpha_{\text {line }}\right)\right)
$$

where $F$ is the pulling force, $h_{\text {anchor }}$ is the fixation height of the pulling line on the sample tree, and $\alpha_{\text {line }}$ is the slope angle of the pulling line. Stem curvature $\left(\mathrm{N}_{\Delta},{ }^{\circ}\right)$ was calculated as the difference between simultaneous tilt measurements at the base and at the height of $5 \mathrm{~m}$ on the stem:

$$
\mathrm{N}_{\Delta}=\mathrm{N}_{5 \mathrm{~m}}-\mathrm{N}_{\text {base }}
$$


$\mathrm{BBM}$ and $\mathrm{N}_{\Delta}$ were used to determine the stability proxies, such as primary $(\mathrm{PF})$ and secondary (SF) failures. During stem bending, the initiation of wood structure deformation occurs under the compression as the kinking of wood fibers, which is not visually observable [54]. Such damage is recognized as PF and can be detected by graphical inspection as the end of proportional increase in BBM and $\mathrm{N}_{\Delta}[54,55]$. The occurrence of SF maximum was considered when reaching the maximum BBM sample tree failed either as uprooting or stem breakage. Additionally, BBM at the stem base inclination of $0.25^{\circ}\left(\mathrm{BBM}_{025}\right)$ was detected. A strong linear relationship between $\mathrm{BBM}_{\mathrm{SF}}$ and $\mathrm{BBM}_{025}$ was reported [56], thus inclination of $0.25^{\circ}$ is frequently used as a threshold in non-destructive tree stability assessments $[57,58]$ as stem bending until such level of basal inclination is considered to be harmless [59]. The applicability of $\mathrm{BBM}_{025}$ in estimation of $\mathrm{BBM}_{\mathrm{SF}}$ for both forest and urban trees was tested.

Stem stiffness of sample trees was estimated by the modulus of elasticity (MOE) which was calculated as follows [35]:

$$
M O E=\frac{B B M \cdot y}{I \cdot e}
$$

where $B B M$ is the bending moment of the stem at the height of a strain gauge, $y$ is the distance from the center of the stem to the center of the strain gauge, $I$ is the area moment of inertia of the section, and $e$ is the strain.

The equation of volume of an elliptical paraboloid was used to calculate the volume of the soil-root plate as follows:

$$
\mathrm{V}=\left(\frac{1}{2}\right) \cdot \pi \cdot a \cdot b \cdot h
$$

where $h$ is the depth of the soil-root plate; $a$ and $b$ are the longest and shortest radii of the root-plate, respectively.

Linear mixed effect models were used to evaluate the differences in mechanical stability proxies $\left(\mathrm{BBM}_{\mathrm{PF}}, \mathrm{BBM}_{\mathrm{SF}}\right.$, and $\left.\mathrm{MOE}\right)$ between the species. The general form of model was:

$$
y_{i j}=\mu+\operatorname{dim}_{i j}+s p_{j}+\operatorname{dim}_{i j} \times s p_{j}+\left(s i t e_{j}\right)+\varepsilon
$$

where $\operatorname{dim}_{i j}$ is the covariate of tree dimensions, $s p_{j}$ is the fixed effect of species, and $\operatorname{dim}_{i j} \times$ $s p_{j}$ is the interaction between tree dimensions and species. Considering relatively small sample size and uneven distribution of sample trees among forest stands, site effect was estimated with it included as a random factor in the models $\left(s_{i t} e_{j}\right)$. Parameters, such as stem slenderness, $\mathrm{GWC}_{\text {soil }}$ and soil density, pulling direction and soil-root plate volume were tested as additional proxies for site effect. Tested covariates of tree dimensions were tree height $(\mathrm{H})$, stem diameter at breast height $(\mathrm{DBH})$, and stem-wood volume $\left(\mathrm{V}_{\text {stem }}\right)$ which were calculated according to locally developed functions for both aspen and birch:

$$
\begin{aligned}
& V_{\text {aspen }}=0.0000502 \times \mathrm{H}^{0.92625} \times \mathrm{DBH}^{0.02221 \times 0.4343 \times \mathrm{LN}(\mathrm{H})+1.95538} \\
& \mathrm{~V}_{\text {birch }}=0.0000909 \times \mathrm{H}^{0.71677} \times \mathrm{DBH}^{0.16692 \times 0.4343 \times \mathrm{LN}(\mathrm{H})+1.7570}
\end{aligned}
$$

where $\mathrm{H}$ is in $\mathrm{m}$ and $\mathrm{DBH}$ is in $\mathrm{cm}$. The collinearity among the variables in the model was tested by the variance inflation, and the predictors with the criterion $<5$ were included. Overall significance of the model was estimated by the maximum likelihood approach. Linear mixed models were used to test the differences in BBM $\mathrm{SF}_{\mathrm{S}}$ between urban and forest birch trees in accordance with main tree-level variables, such as DBH, height, and stem volume. Data statistical analysis was performed in $\mathrm{R}$ software (version 4.1.0.) [60] using the packages "lme4" [61], "lmerTest" [62], and "MuMIn" [63]. 


\section{Results and Discussion}

\subsection{Comparison of Aspen and Birch}

The mechanical stability of the studied tree species differed, with birch being more stable than aspen (Figure 1, Tables 2 and 3). Similarly to previous studies [35,37,52], strong relation between mechanical stability and dimensions of aboveground parts has been found as both $\mathrm{BBM}_{\mathrm{PF}}$ and $\mathrm{BBM}_{\mathrm{SF}}$ were tightly linked $(p<0.001)$ to $\mathrm{V}_{\text {stem }}$ (Table 3). However, in linear-mixed effect models, the interaction effect between $V_{\text {stem }}$ and species (Table 2) was significant for both $\mathrm{BBM}_{\mathrm{PF}}(p=0.011)$ and $\mathrm{BBM}_{\mathrm{SF}}(p=0.017)$ indicating differences in regression slopes (Figure 1, Table 3). Accordingly, for aspen the reduction in resistance against loading at both $\mathrm{BBM}_{\mathrm{PF}}$ and $\mathrm{BBM}_{\mathrm{SF}}$ was 13.2 and $15.8 \%$, respectively compared to that of birch. This suggests higher probability of occurrence of mechanical damages such as PF and subsequent SF for aspen compared with similar-sized birch. Additionally, the ratio of $\mathrm{BBM}_{\mathrm{PF}}$ and $\mathrm{BBM}_{\mathrm{SF}}\left(\mathrm{BBM}_{\mathrm{DIF}}\right)$ was significantly lower $(p=0.002)$ for aspen $(66.7 \%)$ compared to birch (71.2\%) (Tables 2 and 3), implying earlier occurrence of PF in relation to SF. PF implies that during the stem bending, irreversible damages to the wood fibers have occurred which are not visually observable $[54,55,64]$, and such damages can notably affect tree water relations $[54,55]$. This suggests aspen has a higher risk of accumulation of structural wood damages, and each reoccurrence of such damage weakens the tree as the recovery period can be long [65]. Furthermore, the effect of structural wood damage such as PF might be stronger if it coincides with additional anthropogenic stresses, especially in urbanized areas [66]. Thus, long-term wind damage risk might be more pronounced for aspen, as the reduction in vitality can make it hazardous [67].

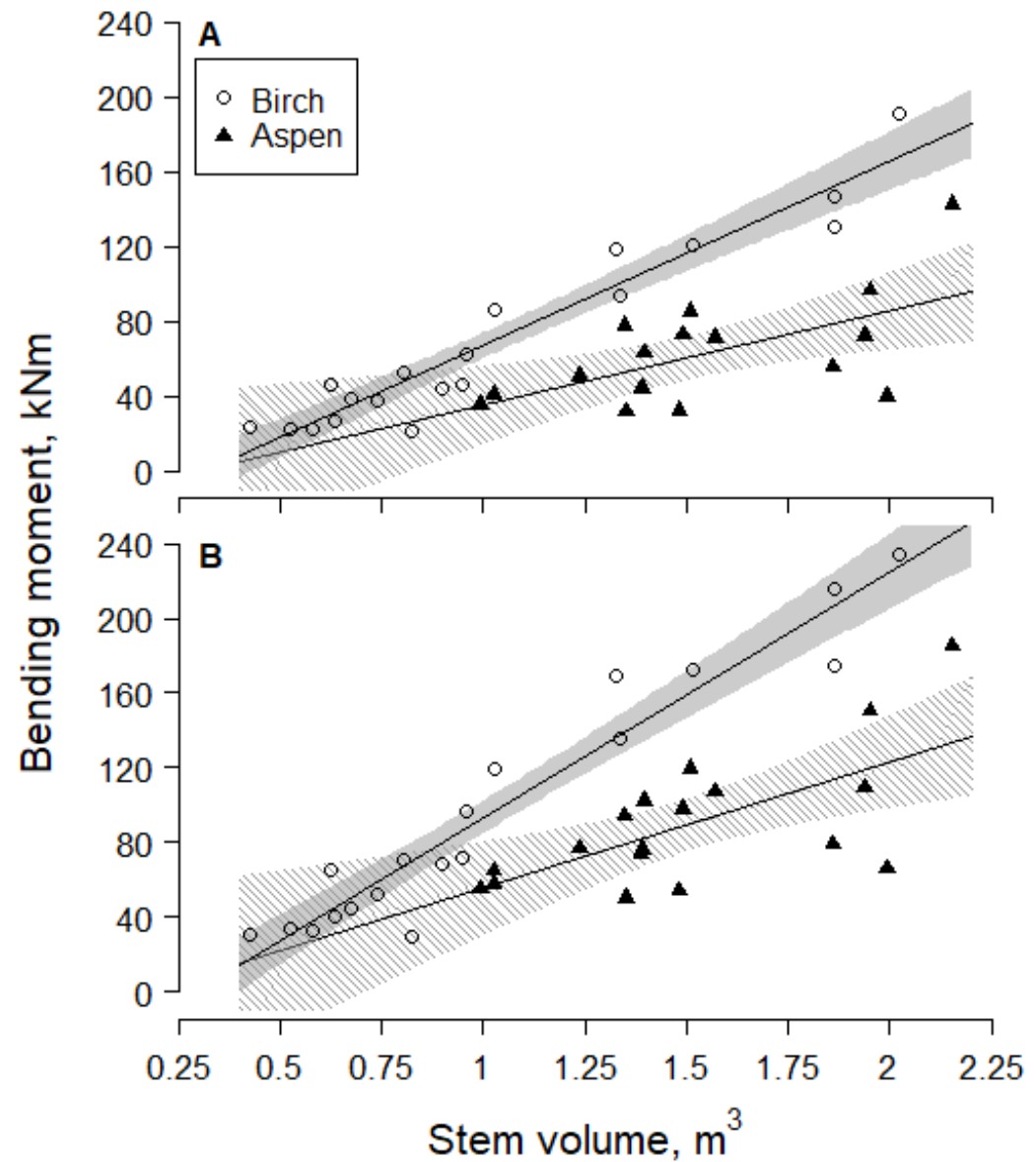

Figure 1. Basal bending moment of common aspen and silver birch stems at the (A) primary failure $\left(\mathrm{BBM}_{\mathrm{PF}}\right)$ and the $(\mathrm{B})$ secondary failure $\left(\mathrm{BBM}_{\mathrm{SF}}\right)$ The coloured area indicates $95 \%$ confidence interval. 
Table 2. Mean ( $\pm 95 \%$ confidence interval) basal bending moment of aspen and birch at primary $\left(\mathrm{BBM}_{\mathrm{PF}}\right)$ and secondary failures $\left(\mathrm{BBM}_{\mathrm{SF}}\right)$ and the difference between them $\left(\mathrm{BBM}_{\mathrm{DIF}}\right)$, the modulus of elasticity (MOE), and the number of trees with stem failure in each sampled site.

\begin{tabular}{cccccc}
\hline Site No. & $\begin{array}{c}\mathbf{B B M}_{\mathbf{P F}} \\
\mathbf{( k N m )}\end{array}$ & $\begin{array}{c}\mathbf{B B M}_{\mathbf{S F}} \\
\mathbf{( k N m )}\end{array}$ & $\begin{array}{c}\mathbf{B B M}_{\mathbf{D I F}} \\
\mathbf{( k N m )}\end{array}$ & MOE (GPa) & $\begin{array}{c}\text { Stem } \\
\text { Breakage, }\end{array}$ \\
\hline Aspen & & & & \\
\hline 1 & $56.0 \pm 24.2$ & $89.7 \pm 34.9$ & $33.7 \pm 11.1$ & $9.5 \pm 2.4$ & 5 \\
2 & $36.6 \pm 9.6$ & $54.0 \pm 7.6$ & $17.5 \pm 2.0$ & $7.4 \pm 0.2$ & 1 \\
3 & $75.0 \pm 39.2$ & $106.0 \pm 47.7$ & $31.1 \pm 9.4$ & $8.1 \pm 0.9$ & 6 \\
4 & $59.4 \pm 32.3$ & $84.1 \pm 37.8$ & $24.7 \pm 14.1$ & $8.7 \pm 1.2$ & 1 \\
\hline Birch & & & & \\
\hline 5 & $33.5 \pm 8.3$ & $46.9 \pm 11.6$ & $13.4 \pm 4.2$ & $13.9 \pm 2.3$ & 0 \\
6 & $110.9 \pm 34.0$ & $154.3 \pm 40.8$ & $43.4 \pm 9.6$ & $15.7 \pm 2.8$ & 0 \\
Karlsruhe & - & $102.3 \pm 25.5$ & - & $7.5 \pm 2.3$ & 0 \\
Hamburg & - & $107.7 \pm 36.0$ & - & $9.6 \pm 1.1$ & 0 \\
\hline
\end{tabular}

Table 3. Statistics of the linear mixed-effects models relating basal bending moment of aspen and birch growing in forest at the primary $\left(\mathrm{BBM}_{\mathrm{PF}}\right)$ and secondary $\left(\mathrm{BBM}_{\mathrm{SF}}\right)$ failures and the difference between them $\left(\mathrm{BBM}_{\mathrm{DIF}}\right)$, and the modulus of elasticity $(\mathrm{MOE})$ of aspen and birch stems under static loading.

\begin{tabular}{|c|c|c|c|c|c|c|c|c|}
\hline \multirow[b]{2}{*}{ Predictors } & \multicolumn{2}{|c|}{$\mathbf{B B M}_{\mathrm{PF}}$} & \multicolumn{2}{|c|}{$\mathrm{BBM}_{\mathrm{SF}}$} & \multicolumn{2}{|c|}{$\mathbf{B B M}_{\text {DIF }}$} & \multicolumn{2}{|c|}{ MOE } \\
\hline & Est. & $p$-Value & Est. & $p$-Value & Est. & $p$-Value & Est. & $p$-Value \\
\hline Intercept & -19.15 & 0.33 & -18.7 & 0.44 & 1.01 & 0.90 & 8.63 & $<0.001$ \\
\hline $\mathrm{V}_{\text {stem }}$ & 52.52 & $<0.001$ & 70.76 & $<0.001$ & 17.88 & $<0.01$ & & \\
\hline Species & -9.82 & 0.68 & -8.29 & 0.78 & 2.12 & 0.85 & 6.12 & $<0.001$ \\
\hline$V_{\text {stem }}$ by species & 43.71 & 0.01 & 50.51 & 0.01 & 6.10 & 0.42 & & \\
\hline \multicolumn{9}{|l|}{ Random Effects } \\
\hline$\sigma^{2}$ & 312.47 & & 448.78 & & 54.45 & & 7.33 & \\
\hline$\tau_{00}$ & 78.29 & & 168.87 & & 36.84 & & 0.13 & \\
\hline ICC & 0.20 & & 0.27 & & 0.40 & & 0.02 & \\
\hline $\mathrm{N}_{\text {site }}$ & 6 & & 6 & & 6 & & 6 & \\
\hline Observations & 37 & & 37 & & 37 & & 37 & \\
\hline Marginal $\mathrm{R}^{2}$ & 0.76 & & 0.76 & & 0.48 & & 0.56 & \\
\hline Conditional $\mathrm{R}^{2}$ & 0.81 & & 0.83 & & 0.69 & & 0.57 & \\
\hline
\end{tabular}

Differences in soil-root anchorage and stem-wood stiffness between the species were underlined by the type of SF; most of the sampled aspen (13 out of 18) experienced stem breakage while all birches uprooted (Table 3). Uprooting is considered to occur due to insufficient soil-root anchorage, thus lower loads are required compared with stem breakage $[19,68,69]$. Soil-root anchorage is largely determined by the architecture of the root system [70] and soil properties, as lower soil density and increase in saturation of moisture facilitate uprooting $[15,19,69]$. However, increased $\mathrm{GWC}_{\text {soil }}$ for aspen $(p<0.001)$ (Table 1) did not appear to be connected to soil-root anchorage. Aspen tends to develop a deeper root system compared to birch [67,71], and root suckering ensures a wide rooting network, facilitating anchorage of neighbouring trees [72]. Meanwhile, uprooting of birch growing on dry mineral soils appears to be facilitated by reduced soil-root plate volume in combination with larger proportion of aboveground parts [37,71]. Still, no significant differences in BBM were observed between aspen trees with different types of failure, similarly to birch in a previous study [37], implying that local conditions might affect the strength of soil-root anchorage [73]. Therefore, stem wood stiffness appears to be crucial in tree mechanical stability [74]. 
Among the measures of stiffness, MOE is among the most common ones [75], which characterizes the change in the dimension of a material under loading and proportionally corresponds to wood density [76]. The stem-wood stiffness differed between species, as MOE for aspen was significantly lower, reaching $59 \%$ of that of birch (Tables 2 and 3). Thus, more frequent stem breakage and hence lower stability for aspen can be explained by stronger soil-root anchorage in combination with lower stiffness of stem-wood. However, as site-dependent characteristics in mechanical stability might be pronounced [74], the effect of studied sites was included in the models as a random effects. Linear mixed-effects models indicated a relatively small effect $(0.2 \%$ of total variance) of site was estimated for MOE, which emphasize smaller differences in stem-wood stiffness of same species between different sites. Therefore, MOE is species-specific, and little affected by the microsite conditions. However, the study site had 20 and $27 \%$ influence on both $\mathrm{BBM}_{\mathrm{PF}}$ and $\mathrm{BBM}_{\mathrm{SF}}$, respectively (Table 3). Thus, a relatively high effect of site conditions [77] on the variation in mechanical stability was estimated.

The microsite conditions can be highly responsible for the mechanical stability, especially in urbanized areas where root distribution may be limited, as well as higher frequency of mechanical damages [12]. However, tree safety might be species-dependent and aspen is suggested to be more vulnerable to wind damage than birch, as significantly lower loading was required to reach both PF and SF (Figure 1). Furthermore, low stiffness of stem-wood and sufficient soil-root anchorage resulted in stem breakage-a failure type which is considered to be more dangerous compared to uprooting $[37,78,79]$. During stem breakage, it may rupture unpredictably as the fragmented parts may fall, causing significant damage to surrounding objects [80]. For comparison, when uprooting occurs, slower motion of whole tree is considered [81]. Therefore, due to lower loading resistance and stem breakage as a common SF, aspen can be considered to become hazardous if located alongside potential targets in urbanized areas, such as roads and pathways. However, similar to rural forests, diversity of tree species of urban forests is of high importance, assisting with resilience against both biotic and abiotic stresses [82]. Therefore, the physical condition of aspen should be monitored particularly carefully to keep it safe, especially in areas with nearby target objects. Additionally, monitoring of tree physical condition and appropriate tree-care management is required in maintenance of tree safety [78]. This is important particularly in urban and peri-urban forests, where trees might easily become hazardous due to limited growing space and anthropogenic stresses [83].

\subsection{Comparison of Urban and Forest Birch Trees}

The mechanical stability of birch did not differ significantly $(p=0.164)$ between urban and forest sites, as the BBM $\mathrm{SF}$ was similar for both groups (Figure 2, Table 4). Correspondingly with trees growing in forest [37], the best relation of $\mathrm{BBM}_{\mathrm{SF}}$ of urban birch appeared to be with $\mathrm{V}_{\text {stem }}(p<0.001)$ (Table 4$)$. The second hypothesis was approved, indicating that static tree-pulling tests are comparable regardless of the growing environment, as similar behaviour of urban and forest birch was observed as shown by a similar effect of $V_{\text {stem }}$ on both groups. Therefore, the adaptation of growth that ensures the mechanical stability was indicated, as the soil-root anchorage of birch follows a universal relationship with $\mathrm{V}_{\text {stem }}$ regardless of the growing environment. Furthermore, birch in forest sites were significantly taller and smaller in $\mathrm{DBH}$, and slenderness differed- $\mathrm{H} / \mathrm{DBH}$ for forest trees reached 1.05 ( 0.52 for urban trees). Slender and taller trees are considered to have lower mechanical stability due to their higher centre of gravity [84]. Likely to compensate for this, forest trees formed stiffer wood, as shown by significantly higher MOE (Table 2), indicating high plasticity of adaptations to growing environment $[75,76,84]$. Alternatively, this might also be provenance-specific $[17,84]$. However, the soil-root anchorage appears to be dependent on the success of wood formation, as trees tend to balance biomass distribution between roots and aboveground parts [85]. Therefore, $\mathrm{V}_{\text {stem }}$ can be used as a universal variable for characterizing a soil-root anchorage of birch regardless of the growing environment. 

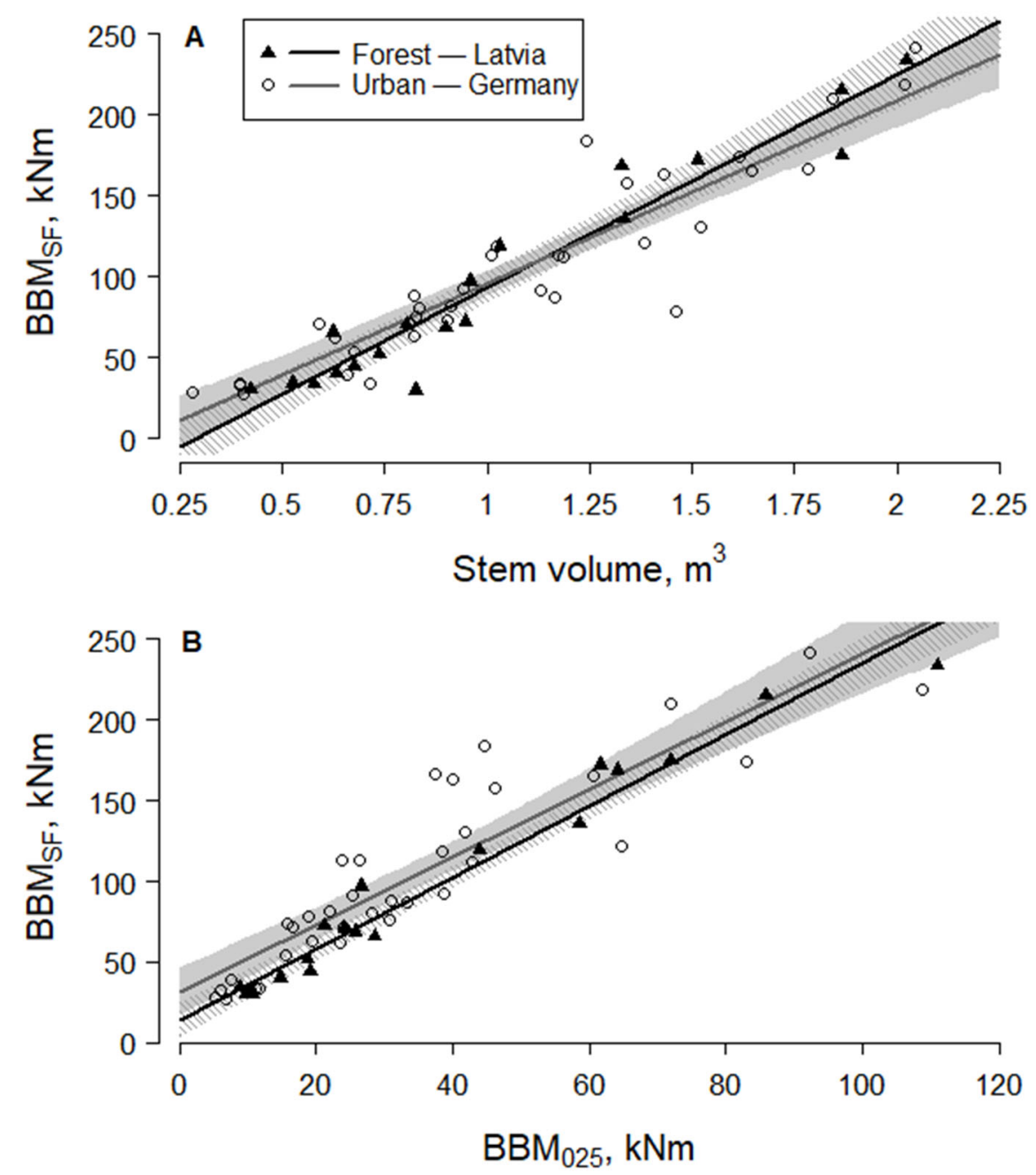

Figure 2. Basal bending moment of silver birch stems at the secondary failure $\left(\mathrm{BBM}_{\mathrm{SF}}\right)$ against stem volume (A) and the basal bending moment at the stem base inclination of $0.25^{\circ}\left(\mathrm{BBM}_{025}\right)(\mathbf{B})$. The shaded area indicates $95 \%$ confidence interval.

Table 4. Regression between basal bending moment of birch at secondary failure (BBM $\mathrm{SF})$, stem volume and basal bending moment at the stem base inclination of $0.25^{\circ}\left(\mathrm{BBM}_{025}\right)$ by the location in urban or forest sites.

\begin{tabular}{|c|c|c|}
\hline & F-Value & $p$-Value \\
\hline Stem volume & 386.71 & $<0.001$ \\
\hline Location (urban or peri-urban forest) & 0.05 & 0.81 \\
\hline Stem volume by location interaction & 1.99 & 0.16 \\
\hline $\mathrm{R}^{2}$ & \multirow{2}{*}{\multicolumn{2}{|c|}{$\begin{array}{c}0.88 \\
<0.001\end{array}$}} \\
\hline Model overall significance, $p$-value & & \\
\hline $\mathrm{BBM}_{025}$ & 350.73 & $<0.001$ \\
\hline Urban or peri-urban forest & 4.38 & 0.04 \\
\hline $\mathrm{BBM}_{025}$ by location interaction & 0.27 & 0.60 \\
\hline $\mathrm{R}^{2}$ & \multirow{2}{*}{\multicolumn{2}{|c|}{$\begin{array}{c}0.87 \\
<0.001\end{array}$}} \\
\hline Model overall significance, $p$-value & & \\
\hline
\end{tabular}

In an urban environment, the characterization of mechanical stability is required to be performed in a non-destructive manner by applying loading thresholds that can estimate the $\mathrm{BBM}_{\mathrm{SF}}$ [86]. One such approach intends for the tree to be pulled to a stem base inclination of $0.25^{\circ}$, which is considered harmless for a tree [87]. The relationship 
between $\mathrm{BBM}_{025}$ and $\mathrm{BBM}_{\mathrm{SF}}$ appeared to be linear and tight $\left(\mathrm{R}^{2}=0.87\right)$ for all tested birch trees in both urban and forest sites (Figure 2, Table 4). Thus, pulling up to inclination threshold of $0.25^{\circ}$ is suggested to provide comparable predictions of $\mathrm{BBM}_{\mathrm{SF}}$ for birch regardless of the growing environment. Nevertheless, in a linear model, the location of sample trees was statistically significant $(p=0.041)$, predicting higher $\mathrm{BBM}_{\mathrm{SF}}$ for urban birch, which might lead to a marginal underestimation. Additionally, urban trees showed higher variability of $\mathrm{BBM}_{\mathrm{SF}}$ (Figure 2) implying higher heterogeneity of microsite conditions as typical among different functional zones of urbanized areas $[4,9,21]$. However, such differences can be considered minute, since slopes were highly similar $(p=0.600)$ (Figure 2, Table 4). Therefore, the robustness of application of the inclination threshold of $0.25^{\circ}$ for estimation of the $\mathrm{BBM}_{\mathrm{SF}}$ can be encouraged for comparing urban and forest trees.

\section{Conclusions}

The results of this study indicated silver birch was more resistant against static loading compared with Eurasian aspen. However, in urban forests maintenance of tree safety is particularly necessary, therefore the physical condition of both species should be kept in scope equally to ensure the necessary activities for safety improvement. The attainment of such an aim can be facilitated by the evaluation of objectively comparable information about mechanical stability. A static pulling test has proven suitable for comparing the mechanical stability, particularly for trees from completely different growing conditions. This method examines universal characteristics of mechanical stability of trees, therefore it is highly useful in urbanized areas with uneven microsite conditions for tree growth. Furthermore, non-destructive testing by applying pulling thresholds can be effectively implemented for both urban and peri-urban trees, thus a significant input for the assessment of mechanical stability can be provided.

Supplementary Materials: The following supporting information can be downloaded at: https: //www.mdpi.com/article/10.3390/f13010127/s1, Figure S1. A scheme of the destructive static pulling test setup. AP1 and AP2-anchor points; $\mathrm{PB}$ - pulley block; PR-polyester rope; ELextension line; DI - dynamometer; $\alpha$-the slope angle of the pulling line; 11 -the distance between the sample tree and the anchoring tree; IM0 and IM5-inclinometers at the height of 0 and $5 \mathrm{~m}$, respectively; EM-elastometer; $\mathrm{H}$-tree height; $\mathrm{TH}-$ topping height. Figure S2. A scheme of the location of winch in the static pulling test setup. AP1, AP2 and AP3 - anchor points; MW-motor winch; PB — pulley block; PR—polyester rope; EL—extension line; DI—dynamometer.

Author Contributions: Conceptualization, O.K., L.Č. and S.R.; methodology, R.M. and D.E.; formal analysis, L.Č., D.E., O.K. and S.R.; data curation, A.S. and Ä.J.; writing-original draft preparation, L.Č., O.K. and R.M.; writing-review and editing, Ā.J. and S.R.; supervision, Ā.J.; project administration, Ā.J. All authors have read and agreed to the published version of the manuscript.

Funding: ERDF project "Birch and aspen stand management decision support tool for reduction of wind damages" (No 1.1.1.1/18/A/134).

Data Availability Statement: The data presented in this study are available on request from the corresponding author. The data are not publicly available due to policy of the institute.

Acknowledgments: Authors appreciate the input of researcher Janis Donis in discussions that helped to improve the manuscript and help in data collection by Ilvars Ievinš and Andis Adamovičs.

Conflicts of Interest: The authors declare no conflict of interest.

\section{References}

1. Egidi, G.; Salvati, L.; Vinci, S. The long way to tipperary: City size and worldwide urban population trends, 1950-2030. Sustain. Cities Soc. 2020, 60, 102148. [CrossRef]

2. Gulsrud, N.M.; Nielsen, A.B.; Bastrup-Birk, A.; Olafsson, A.S.; Lier, M.; Fischer, C.; Zalkauskas, R.; Hedblom, M.; Sievanen, T.; Nordh, H.; et al. Urban Forests in a European Perspective: What Can the National Forest Inventory Tell Us. In Proceedings of the Workshop for Practitioners and Researchers", Brussels, Belgium, 15 March 2018; Department of Geosciences and Natural Resource Management, University of Copenhagen: København, Denmark, 2018. 
3. Stone, B.; Rodgers, M.O. Urban form and thermal efficiency: How the design of cities influences the urban heat island effect. J. Am. Plan. Assoc. 2001, 67, 186-198. [CrossRef]

4. Livesley, S.J.; McPherson, E.G.; Calfapietra, C. The Urban Forest and Ecosystem Services: Impacts on Urban Water, Heat, and Pollution Cycles at the Tree, Street, and City Scale. J. Environ. Qual. 2016, 45, 119-124. [CrossRef] [PubMed]

5. Yang, J.; McBride, J.; Zhou, J.; Sun, Z. The urban forest in Beijing and its role in air pollution reduction. Urban For. Urban Green. 2005, 3, 65-78. [CrossRef]

6. Zhao, M.; Zhang, J.; Xie, J.; Zhang, M. Empirical study on recreation suitability evaluation of suburban forest park-A case study of Baiyun forest park in Lishui city, China. Appl. Ecol. Environ. Res. 2019, 17, 3499-3512. [CrossRef]

7. Kenney, W.A. A strategy for Canada's urban forests. For. Chron. 2003, 79, 785-789. [CrossRef]

8. Nowak, D.J.; Dwyer, J.F. Understanding the Benefits and Costs of Urban Forest Ecosystems. In Handbook of Urban and Community Forestry in the Northeast; Kuser, J.E., Ed.; Springer: Boston, MA, USA; New York, NY, USA, 2000; pp. 11-25.

9. Czaja, M.; Kołton, A.; Muras, P. The complex issue of urban trees-stress factor accumulation and ecological service possibilities. Forests 2020, 11, 932. [CrossRef]

10. Hunt, A.; Watkiss, P. Climate change impacts and adaptation in cities: A review of the literature. Clim. Chang. 2011, 104, 13-49. [CrossRef]

11. Seidl, R.; Thom, D.; Kautz, M.; Martin-benito, D.; Peltoniemi, M.; Vacchiano, G.; Wild, J.; Ascoli, D.; Petr, M.; Honkaniemi, J.; et al. Forest disturbances under climate change. Nat. Clim. Chang. 2017, 7, 395-402. [CrossRef]

12. Solecki, W.; Marcotullio, P.J. Climate Change and Urban Biodiversity Vulnerability. In Urbanization, Biodiversity and Ecosystem Services: Challenges and Opportunities: A Global Assessment; Elmqvist, T., Fragkias, M., Goodness, J., Guneralp, B., Marcotullio, P.J., McDonald, R.I., Parnell, S., Schewenius, M., Sendstad, M., Seto, K.C., et al., Eds.; Springer Opem: Dordrecht The Netherlands; Heidelberg, Germany; New York, NY, USA; London, UK, 2013; pp. 453-459. ISBN 9789400770881.

13. Sani, L.; Lisci, R.; Moschi, M.; Sarri, D.; Rimediotti, M.; Vieri, M.; Tofanelli, S.; Tofanelli, S. Preliminary experiments and verification of controlled pulling tests for tree stability assessments in Mediterranean urban areas. Biosyst. Eng. 2012, 112, 218-226. [CrossRef]

14. James, K.R.; Haritos, N.; Ades, P.K. Mechanical stability of trees under dynamic loads. Am. J. Bot. 2006, 93, 1522-1530. [CrossRef]

15. Nicoll, B.C.; Ray, D. Adaptive growth of tree root systems in response to wind action and site conditions. Tree Physiol. 1996, 16, 891-898. [CrossRef] [PubMed]

16. Peltola, H.; Ikonen, V.P.; Gregow, H.; Strandman, H.; Kilpeläinen, A.; Venäläinen, A.; Kellomäki, S. Impacts of climate change on timber production and regional risks of wind-induced damage to forests in Finland. For. Ecol. Manag. 2010, 260, 833-845. [CrossRef]

17. Ståhl, E.G. Changes in wood and stem properties of Pinus sylvestris caused by provenance transfer. Silva Fenn. 1998, 32, 163-172. [CrossRef]

18. Giambastiani, Y.; Preti, F.; Errico, A.; Sani, L. On the tree stability: Pulling tests and modelling to assess the root anchorage. Procedia Environ. Sci. Eng. Manag. 2017, 4, 207-218.

19. Moffat, A.; Nisbet, T.; Nicoll, B. Environmental Effects of Stump and Root Harvesting; Forestry Commission: Edinburgh, Scotland, 2011.

20. Weltecke, K.; Gaertig, T. Influence of soil aeration on rooting and growth of the Beuys-trees in Kassel, Germany. Urban For. Urban Green. 2012, 11, 329-338. [CrossRef]

21. Lindsey, P.; Bassuk, N. Specifying soil volumes to meet the water needs of mature urban street trees and trees in containers. J. Arboric. 1991, 17, 141-149. [CrossRef]

22. Stubbs, C.J.; Cook, D.D.; Niklas, K.J. A general review of the biomechanics of root anchorage. J. Exp. Bot. 2019, 70, 3439-3451. [CrossRef] [PubMed]

23. Hekkala, A.M.; Tarvainen, O.; Tolvanen, A. Dynamics of understory vegetation after restoration of natural characteristics in the boreal forests in Finland. For. Ecol. Manag. 2014, 330, 55-66. [CrossRef]

24. Kowarik, I.; von der Lippe, M.; Cierjacks, A. Prevalence of alien versus native species of woody plants in Berlin differs between habitats and at different scales. Preslia 2013, 85, 113-132.

25. Putz, F.E.; Coley, P.D.; Lu, K.; Montalvo, A.; Aiello, A. Uprooting and snapping of trees: Structural determinants and ecological censequences. Can. J. For. Res. 1983, 13, 1011-1020. [CrossRef]

26. Halme, P.; Purhonen, J.; Marjakangas, E.L.; Komonen, A.; Juutilainen, K.; Abrego, N. Dead wood profile of a semi-natural boreal forest-implications for sampling. Silva Fenn. 2019, 53, 1-14. [CrossRef]

27. Rich, R.L.; Frelich, L.E.; Reich, P.B. Wind-throw mortality in the southern boreal forest: Effects of species, diameter and stand age. J. Ecol. 2007, 95, 1261-1273. [CrossRef]

28. Petrokas, R.; Baliuckas, V.; Manton, M. Successional categorization of european hemi-boreal forest tree species. Plants 2020, 9 , 1381. [CrossRef] [PubMed]

29. Dyderski, M.K.; Paź, S.; Frelich, L.E.; Jagodziński, A.M. How much does climate change threaten European forest tree species distributions? Glob. Chang. Biol. 2018, 24, 1150-1163. [CrossRef]

30. Kneeshaw, D.; Bergeron, Y. Canopy Gap Characteristics and Tree Replacement in the Southeastern Boreal Forest. Ecology 1998, 79 , 783-794. [CrossRef]

31. Urban Forestry in the Nordic and Baltic Countries; Sander, H.; Randrup, T.B. (Eds.) Estonian Agricultural University, Department of Forestry, Forest Research Institute: Tallinn, Estonia; Copenhagen, Denmark, 1998; p. 77. 
32. Atkinson, M.D. Betula pendula Roth (B. Verrucosa Ehrh.) and B. Pubescens Ehrh. J. Ecol. 1992, 80, 837-870. [CrossRef]

33. Caudullo, G.; Commission, E.; Rigo, D. De Populus tremula in Europe: Distribution, habitat, usage and threats. In European Atlas of Forest Tree Species; San-Miguel-Ayanz, J., de Rigo, D., Caudullo, G., Houston Durrant, T., Mauri, A., Eds.; Off. EU.: Luxembourg, 2016; p. 148.

34. Esseen, P.A.; Ehnström, B.; Ericson, L.; Sjöberg, K. Boreal forests. In Boreal Ecosystems and Landscapes: Structures, Processes and Conservation of Biodiversity; Hansson, Ed.; Ecological Bulletins; Munksgaard: Copenhagen, Denmark, 1997; Volume 46, pp. 16-47.

35. Peltola, H.; Kellomäki, S.; Hassinen, A.; Granander, M. Mechanical stability of Scots pine, Norway spruce and birch: An analysis of tree-pulling experiments in Finland. For. Ecol. Manag. 2000, 143-153. [CrossRef]

36. Čakša, L.; Šēnhofa, S.; Šnepsts, G.; Elferts, D.; Liepa, L.; Jansons, Ā. Effect of stem snapping on aspen timber assortment recovery in hemiboreal forests. Forests 2021, 12, 28. [CrossRef]

37. Krišāns, O.; Matisons, R.; Kitenberga, M.; Donis, J.; Rust, S.; Elferts, D.; Jansons, Ā. Wind resistance of eastern Baltic silver birch (Betula pendula Roth.) suggests its suitability for periodically waterlogged sites. Forests 2021, 12, 21. [CrossRef]

38. Jankovska, I.; Donis, J.; Straupe, I.; Panagopoulos, T.; Kupfere, L. Assessment of forest recreation accessibility in Latvia. Fresenius Environ. Bull. 2013, 22, 2145-2151.

39. Liepinš, J.; Lazdinš, A.; Liepinš, K. Equations for estimating above- and belowground biomass of Norway spruce, Scots pine, birch spp. and European aspen in Latvia. Scand. J. For. Res. 2018, 33, 58-70. [CrossRef]

40. Lygis, V.; Bakys, R.; Gustiene, A.; Burokiene, D.; Matelis, A.; Vasaitis, R. Forest self-regeneration following clear-felling of dieback-affected Fraxinus excelsior: Focus on ash. Eur. J. For. Res. 2014, 133, 501-510. [CrossRef]

41. Veinberga, M.; Zigmunde, D. Aesthetics and Ecology in Planning of Urban Green Spaces of Latvia. Sci. J. Latv. Univ. Agric. 2016, $8,43-52$.

42. Rydberg, D.; Falck, J. Designing the urban forest of tomorrow: Pre-commercial thinning adapted for use in urban areas in sweden Arboric. J. 1998, 22, 147-171. [CrossRef]

43. Belda, M.; Holtanová, E.; Halenka, T.; Kalvová, J. Climate classification revisited: From Köppen to Trewartha. Clim. Res. 2014, 59, 1-13. [CrossRef]

44. Jaagus, J.; Briede, A.; Rimkus, E.; Remm, K. Precipitation pattern in the Baltic countries under the influence of large-scale atmospheric circulation and local. Int. J. Climatol. 2010, 30, 705-720. [CrossRef]

45. LEGMC Latvian Environment, Geology and Meteorology Centre. Available online: https://klimats.meteo.lv/klimats/latvijas_ klimats / (accessed on 19 January 2016).

46. Lizuma, L. An Analysis of a Long-Term Meteorological Data Series in Riga. Folia Geogr. 2000, 7, 53-61.

47. Samariks, V.; Krisans, O.; Donis, J.; Silamikele, I.; Katrevics, J.; Jansons, A. Cost-benefit analysis of measures to reduce windstorm impact in pure Norway Spruce (Picea abies L. Karst.) stands in Latvia. Forests 2020, 11, 576. [CrossRef]

48. San-Miguel-Ayanz, J.; de Rigo, J.; Caudullo, D.; Durrant, G.; Mauri, T.; Tinner, A.; Ballian, W.; Beck, D.; Birks, P.; Eaton, H.; et al. European Atlas of Forest Tree Species; Publications Office of the European Union: Luxembourg, 2016.

49. Dahlhausen, J.; Rötzer, T.; Biber, P.; Uhl, E.; Pretzsch, H. Urban climate modifies tree growth in Berlin. Int. J. Biometeorol. 2018, 62, 795-808. [CrossRef]

50. Climate-Data. Available online: https://en.climate-data.org/europe/germany/baden-wuerttemberg/karlsruhe-2143/ (accessed on 14 December 2021)

51. Climate-Data. Available online: https://en.climate-data.org/europe/germany/hamburg/hamburg-69/ (accessed on 14 December 2021).

52. Krisans, O.; Saleniece, R.; Rust, S.; Elferts, D.; Kapostins, R.; Jansons, A.; Matisons, R. Effect of Bark-Stripping on Mechanical Stability of Norway Spruce. Forests 2020, 11, 357. [CrossRef]

53. Krisans, O.; Matisons, R.; Rust, S.; Burnevica, N.; Bruna, L.; Elferts, D.; Kalvane, L.; Jansons, A. Presence of root rot reduces stability of norway spruce (Picea abies): Results of static pulling tests in Latvia. Forests 2020, 11, 416. [CrossRef]

54. Detter, A.; Richter, K.; Rust, C.; Rust, S. Aktuelle Untersuchungen zum Primärversagen von grünem Holz-Current studies on primary failure in green wood. In Proceedings of the Conference Deutsche Baumpflegetage, Augsburg, Germany, 5-7 May 2015; pp. 156-167.

55. Detter, A.; Rust, S.; Rust, C.; Maybaum, G. Determining strength limits for standing tree stems from bending tests. Proceedings of 18th International Nondestructive Testing and Evaluation of Wood Symposium, Madison, WI, USA, 24-27 September 2013; pp. 24-27.

56. Rust, S.; Detter, A. Experimental test of non-destructive methods to assess the anchorage of urban trees. In Proceedings of the 21st international nondestructive testing and evaluation of wood symposium, Freiburg, Germany, 24-27 September 2019.

57. James, K.; Hallam, C.; Spencer, C. Measuring tilt of tree structural root zones under static and wind loading. Agric. For. Meteorol. 2013, 168, 160-167. [CrossRef]

58. Brudi, E.; van Wassenaer, P. Trees and statics: Non-destructive failure analysis. In Proceedings of the Tree Structure and Mechanics Conference: How Trees Stand up and Fall down; ISA: Savannah, GA, USA, October 2001; pp. 53-70.

59. Smiley, E.T.; Coder, K. Tree Structure and Mechanics Conference Proceedings: How Trees Stand up and Fall down; Kim, D., Ed.; ISA: Champaign, IL, USA, 2002.

60. R Core Team. R: A Language and Environment for Statistical Computing. Available online: https://www.r-project.org/ (accessed on 20 May 2019). 
61. Bates, D.; Maechler, M.; Bolker, B.; Walker, S. Fitting Linear Mixed-Effects Models Using lme4. J. Stat. Softw. 2015, 67, 1-48. [CrossRef]

62. Kuznetsova, A.; Brockhoff, P.B.; Christensen, R.H.B. lmerTest Package: Tests in Linear Mixed Effects Models. J. Stat. Softw. 2017, 82, 1-26. [CrossRef]

63. Bartoń, K. MuMIn: Multi-Model Inference. Available online: https://cran.r-project.org/web/packages/MuMIn/index.html (accessed on 24 November 2020).

64. Detter, A.; Van Wassenaer, P.; Rust, S. Stability recovery in London plane trees 8 years after primary anchorage failure. Arboric. Urban For. 2019, 45, 279-288. [CrossRef]

65. Nykänen, M.L.; Peltola, H.; Quine, C.; Kellomäki, S.; Broadgate, M. Factors affecting snow damage of trees with particular reference to European conditions. Silva Fenn. 1997, 31, 193-213. [CrossRef]

66. Hauer, R.J.; Wang, W.; Dawson, J.O. Ice storm damage to urban trees. J. Arboric. 1993, 19, 187-194.

67. Samariks, V.; Brizga, D.; Rūba, J.; Seipulis, A.; Jansons, Ā. Root-plate characteristics of common aspen in hemiboreal forests of Latvia: A case study. Forests 2021, 12, 32. [CrossRef]

68. Szoradova, A.; Praus, L.; Kolarik, J. Evaluation of the root system resistance against failure of urban trees using principal component analysis. Biosyst. Eng. 2013, 115, 244-249. [CrossRef]

69. Laapas, M.; Lehtonen, I.; Venäläinen, A.; Peltola, H.M. The 10-year return levels of maximum wind speeds under frozen and unfrozen soil forest conditions. Climate 2019, 7, 62. [CrossRef]

70. Dupuy, L.; Fourcaud, T.; Stokes, A. A numerical investigation into the influence of soil type and root architecture on tree anchorage. Plant Soil 2005, 278, 119-134. [CrossRef]

71. Samariks, V.; İstenais, N.; Seipulis, A.; Miezīte, O.; Krišāns, O.; Jansons, Ā. Root-soil plate characteristics of silver birch on wet and dry mineral soils in Latvia. Forests 2021, 12, 20. [CrossRef]

72. DesRochers, A.; Lieffers, V.J. The coarse-root system of mature Populus tremuloides in declining stands in Alberta, Canada. J. Veg. Sci. 2001, 12, 355-360. [CrossRef]

73. Ennos, A.R. The mechanics of root anchorage. Adv. Bot. Res. 2000, 33, 133-157. [CrossRef]

74. Taylor, A.M.; Gartner, B.L.; Morrell, J.J. Heartwood formation and natural durability-A review. Wood Fiber Sci. 2002, 34, 587-611.

75. Dahle, G.A.; James, K.R.; Kane, B.; Grabosky, J.C.; Detter, A. A review of factors that affect the static load-bearing capacity of urban trees. Arboric. Urban For. 2017, 43, 89-106. [CrossRef]

76. Niklas, K.J.; Spatz, H.C. Worldwide correlations of mechanical properties and green wood density. Am. J. Bot. 2010, 97, 1587-1594. [CrossRef]

77. Nakagawa, S.; Johnson, P.C.D.; Schielzeth, H. The coefficient of determination $\mathrm{R}^{2}$ and intra-class correlation coefficient from generalized linear mixed-effects models revisited and expanded. J. R. Soc. Interface 2017, 14, 20170213. [CrossRef]

78. Pokorny, J.; O’Brien, J.; Hauer, R.; Johnson, G.; Albers, J.; Bedker, P.; Mielke, M. Urban Tree Risk Management: A Community Guide to Program Design and Implementation; McGuinness, B., Ed.; The U.S. Department of Agriculture: St. Paul, MN, USA, 1992.

79. Silapachote, P.; Srisuphab, A.; Sirilertworakul, V.; Anekwiroj, P. Spectral Analysis of Dynamic Wind Loads on Trees. In Proceedings of the IEEE Region 10 Annual International Conference, Proceedings/TENCON, Jeju, Korea, 28-31 October 2018; pp. 593-598.

80. Miller, R.W.; Hauer, R.J.; Werner, L.P. Urban Forestry: Planning and Managing Urban Greenspaces, 3rd ed.; Robert, W.M., Richard, J.H., Werner, L.P., Eds.; Waveland Press: Long Grove, IL, USA, 2015.

81. Ghani, M.A.; Stokes, A.; Fourcaud, T. The effect of root architecture and root loss through trenching on the anchorage of tropical urban trees (Eugenia grandis Wight). Trees 2009, 23, 197-209. [CrossRef]

82. Korhonen, A.; Siitonen, J.; Kotze, D.J.; Immonen, A.; Hamberg, L. Stand characteristics and dead wood in urban forests: Potential biodiversity hotspots in managed boreal landscapes. Landsc. Urban Plan. 2020, 201, 103855. [CrossRef]

83. Sharon, E.M. Tree failures, risk and reasonableness. A commonsense approach. Arboric. J. 1989, 13, 193-209. [CrossRef]

84. Groot, A.; Cortini, F. The effect of the interaction of tree slenderness and relative height with ring width on wood density in Abies balsamea and Picea glauca. Wood Sci. Technol. 2017, 51, 175-194. [CrossRef]

85. Sinacore, K.; Hall, J.S.; Potvin, C.; Royo, A.A.; Ducey, M.J.; Ashton, M.S. Unearthing the hidden world of roots: Root biomass and architecture differ among species within the same guild. PLoS ONE 2017, 12, e0185934. [CrossRef] [PubMed]

86. Lüttge, U.; Buckeridge, M. Trees: Structure and function and the challenges of urbanization. Trees 2020, 34, 1-8. [CrossRef]

87. Detter, V.A.; Rust, S. Aktuelle Untersuchungsergebnisse zu Zugversuchen, Findings of recent research on the pulling test method. Jahrb. Baumpflege 2013, 17, 87-100. 